\title{
Undifferentiated Carcinoma of Lymph Nodes
}

\section{Wilson Onuigbo*}

Department of Pathology, Medical Foundation and Clinic, Nigeria

Submission: August 06, 2018; Published: September 24, 2018

*Corresponding author: Wilson Onuigbo, Department of Pathology, Medical Foundation and Clinic, 8 Nsukka Lane, Enugu 400001, Nigeria,

Email: wilson.onuigbo@gmail.com

\section{Abstract}

The undifferentiated carcinomas seem to be a problem in terms of the lymph nodes. They were sought in the histological data pool established for the Ibo ethnic group in Nigeria. They were found mostly in females and in the neck. In general, attention is drawn to publications in which "or" appears to be the saving grace when the titles were chosen.

Keywords: Lymph node; Undifferentiated carcinoma; Age; Site; Sex; Definition problem

\section{Introduction}

A survey of the literature on lymph nodes concerning undifferentiated carcinoma is revealing, although some countries stand out. In alphabetical order, they are Costa Rica [1], Germany [2], Hong Kong [3], Japan [4], Korea [5], and Portugal [6]. Therefore, the Nigerian cases are deemed to be worthy of documentation from among the Ibo ethnic group [7]. In fact, this was facilitated by following the example of Birmingham (UK) authors who hypothesized that the establishment of a histopathology data pool facilitates epidemiological analysis [8].

\section{Investigation}

From 1970, the Government of the Eastern Region of Nigeria resuscitated the Pathology Department which was almost destroyed during the Civil War. As the pioneer pathologist, I insisted on receiving biopsy specimens provided that the epidemiological data were written up. Moreover, as I kept personal copies of the Reports, their analysis in tabular form was facilitated.

\section{Results}

(Table 1)

Table 1: Epidemiological data on lymph nodes containing undifferentiated carcinoma.

\begin{tabular}{|c|c|c|c|c|c|c|}
\hline S. No & Initials & Age & Sex & City & Doctor & Site \\
\hline 1 & OA & 65 & M & Uturu & Groin \\
\hline 2 & AS & 55 & F & Umuahia & Imo & Axilla \\
\hline 3 & OF & 66 & F & Enugu & Neck \\
\hline 4 & OT & 48 & F & Enugu & Eruchalu & Neck \\
\hline 5 & AN & 35 & F & Enugu & Madike & Axilla \\
\hline 6 & IB & 72 & M & Auchi & Martins & Onyiah \\
\hline 7 & OG & 79 & M & Enugu & Obianyo & Neck \\
\hline 8 & IO & 3 & F & Enugu & Okorie & Neck \\
\hline 9 & CR & 44 & M & Enugu & Kalu & Groin \\
\hline 10 & ON & 70 & F & Uturu & Enugu & Oxilla \\
\hline 11 & IR & 30 & F & & & Akeke \\
\hline
\end{tabular}

\section{Discussion}

Most of the specimens were received from hospitals based in Enugu. However, two Mission Hospitals situated in Uturu and Umuahia were fruitful. Moreover, the $6^{\text {th }}$ concerned a distant town situated in another State far away. This is in consonance with my view that a central laboratory is useful to distant doctors $[9,10]$. Thus, this opinion opposes the once hotly debated issue in the UK concerning whether such distant laboratories could ever be useful 
[11]. Curiously, some authors were forced to entitle their works with "or" such as in "epidermoid or undifferentiated carcinoma in cervical lymph nodes" [12], and as in "patients presenting with metastatic adenocarcinoma or undifferentiated carcinoma" [13].

In Germany [2], the authors were satisfied that 16 of 18 cases of major salivary gland cancer showed undifferentiated carcinoma. From Hong Kong [3], there was access through fine needle aspiration cytology of lymph node. Concerning the esophagus [4], the Japanese 67-year-old man had "complete response to chemotherapy."

\section{Conclusion}

The comparative cases from Korea [5] were explanatory. Thus, the disparate figures in that country were clearly those of the adenocarcinoma (57\%) and of the undifferentiated carcinoma (9\%). In this context, the latter seems to be relatively uncommon in epidemiological analysis. As to the future, authors are advised to be decisive instead of the indecisive "or" creeping up.

\section{References}

1. Lobo Sanahuja F, Garcia I, Carranza A, Camacho A (1986) Treatment and outcome of undifferentiated carcinoma of the nasopharynx in childhood: A 13-year experience. Pediat Blood Cancer 14(1): 6-11.

2. Stennert E, Kisner D, Jungehuelsin M (2003) High incidence of lymph node metastasis in major salivary gland cancer. Arch Otolaryngol Head Neck Surg 129(7): 720-723.

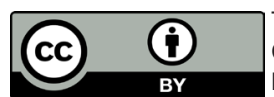

This work is licensed under Creative Commons Attribution 4.0 License DOI: 10.19080/IJCSMB.2018.04.555657
3. Lui PCW, Chow LC, Tsang RKY (2004) Fine needle aspiration cytology of lymph node with metastatic undifferentiated carcinoma and granulomatous (sarcoid-like) reaction. Pathology 36(3): 273-288.

4. Suwa T, Yoshia M, Kubota K (2008) Successful treatment for undifferentiated carcinoma of the esophagus: A case with complete response to chemoradiotherapy. Esophagus 5(1): 51-55.

5. Kim DS, Nam HJ, Choi WH, Lee TS (1991) Metastatic tumors in supraclavicular lymph node: Pathological analysis of 125 cases. Yeungnam Univ J Med 8(2): 70-75.

6. Adelia F, Gil I, Teles T (2017) Intrammary lymph node metastasis of an unknown primary, probably occult breast, undifferentiated carcinoma. F1000Research 6: 265 .

7. Basden GT (1966) Among the Ibos of Nigeria. London: Frank Cass.

8. Macartney JC, Rollaston TP, Codling BW (1980) Use of a histopathology data pool for epidemiological analysis. J Clin Pathol 33: 351-353.

9. Onuigbo WIB, Mbanaso AU (2005) Urban histopathology service for a remote Nigerian hospital. Bull Roy Coll Pathol 132: 32-34.

10. Onuigbo WIB, Anyaeze CM (2009) Biopsy service for surgical practice in mission hospital. Owerri Med J 3: 7-10.

11. Lilleyman J (2002) From the President. Bull Roy Coll Pathol 117:2-3.

12. Silverman CL, Marks JE, Lee F, Ogura JH (1983) Treatment of epidermoid and undifferentiated carcinomas from occult primaries presenting in cervical lymph nodes. Laryngoscope 93(5): 645-648.

13. Kirsten F, Chi CH, Leary JA (1987) Metastatic adeno or undifferentiated carcinoma from an unknown primary site: Natural history and guidelines for identification of treatable subsets. Q J Med 62(238): 143-146.

\section{Your next submission with Juniper Publishers will reach you the below assets}

- Quality Editorial service

- Swift Peer Review

- Reprints availability

- E-prints Service

- Manuscript Podcast for convenient understanding

- Global attainment for your research

- Manuscript accessibility in different formats ( Pdf, E-pub, Full Text, Audio)

- Unceasing customer service

Track the below URL for one-step submission https://juniperpublishers.com/online-submission.php 